\title{
The Role of Microbial Aspartic Protease Enzyme in Food and Beverage Industries
}

\author{
Jermen Mamo (iD) and Fassil Assefa \\ Microbial, Cellular and Molecular Biology Department, College of Natural Science, Addis Ababa University, P.O. Box 1176, \\ Addis Ababa, Ethiopia
}

Correspondence should be addressed to Jermen Mamo; jermenmamo@yahoo.com

Received 3 April 2018; Revised 16 May 2018; Accepted 29 May 2018; Published 3 July 2018

Academic Editor: Antimo Di Maro

Copyright (c) 2018 Jermen Mamo and Fassil Assefa. This is an open access article distributed under the Creative Commons Attribution License, which permits unrestricted use, distribution, and reproduction in any medium, provided the original work is properly cited.

\begin{abstract}
Proteases represent one of the three largest groups of industrial enzymes and account for about $60 \%$ of the total global enzymes sale. According to the Nomenclature Committee of the International Union of Biochemistry and Molecular Biology, proteases are classified in enzymes of class 3, the hydrolases, and the subclass 3.4, the peptide hydrolases or peptidase. Proteases are generally grouped into two main classes based on their site of action, that is, exopeptidases and endopeptidases. Protease has also been grouped into four classes based on their catalytic action: aspartic, cysteine, metallo, and serine proteases. However, lately, three new systems have been defined: the threonine-based proteasome system, the glutamate-glutamine system of eqolisin, and the serine-glutamate-aspartate system of sedolisin. Aspartic proteases (EC 3.4.23) are peptidases that display various activities and specificities. It has two aspartic acid residues (Asp32 and Asp215) within their active site which are useful for their catalytic activity. Most of the aspartic proteases display best enzyme activity at low $\mathrm{pH}$ ( $\mathrm{pH} 3$ to 4 ) and have isoelectric points in the $\mathrm{pH}$ range of 3 to 4.5 . They are inhibited by pepstatin. The failure of the plant and animal proteases to meet the present global enzyme demand has directed to an increasing interest in microbial proteases. Microbial proteases are preferred over plant protease because they have most of the characteristics required for their biotechnological applications. Aspartic proteases are found in molds and yeasts but rarely in bacteria. Aspartic protease enzymes from microbial sources are mainly categorized into two groups: (i) the pepsin-like enzymes produced by Aspergillus, Penicillium, Rhizopus, and Neurospora and (ii) the rennin-like enzymes produced by Endothia and Mucor spp., such as Mucor miehei, M. pusillus, and Endothia parasitica. Aspartic proteases of microbial origin have a wide range of application in food and beverage industries. These include as milk-clotting enzyme for cheese manufacturing, degradation of protein turbidity complex in fruit juices and alcoholic liquors, and modifying wheat gluten in bread by proteolysis.
\end{abstract}

\section{Introduction}

Enzymes are proteins produced by living organisms which catalyze the chemical reaction in greatly efficient ways and are environment friendly. They have substantial advantages over chemical catalysts, in its specificity, high catalytic activity, its capability to work at moderate temperatures, and the ability to be produced in large amounts [1]. The present high demand for better use of renewable resources and the burden on industry to work within an environment-friendly process encouraged the production of new enzyme-catalyst [1].

Proteases represent one of the three major groups of industrial enzymes and occupy $60 \%$ of the total global enzyme sale [1]. They have a wide range of application in various industries to make a change in product taste, texture, and appearance and in waste recovery. Besides this, they have extensive applications in food industry, laundry detergents, leather treatment, bioremediation processes, and pharmaceutical industry. Their depolymerization activity also plays a major role in nutrition. The Novo industry of Denmark is among the major protease producers of the world, which occupies $40 \%$ of the market share of proteases. It produces three types of proteases, such as Aquaderm, NUE, and Pyrase, which are used for soaking, dehairing, and bating, respectively [1].

All cells, tissues, and organisms require proteolysis for growth and metabolism. Even a virus, the smallest nucleic 
acid-based self-replicating organism, typically requires either host cell proteolysis or enzymes coded by its own genetic material to provide processing of initial viral gene products. Microorganisms can be used as an excellent source of protease. The incapability of plant and animal proteases to meet the current global enzyme demand increased the interest for the microbial protease. Microbial protease is preferred than other sources because they possess almost all the characteristics desired for their biotechnological applications [1].

According to the Nomenclature Committee of the International Union of Biochemistry and Molecular Biology, proteases are classified in enzymes of class 3, the hydrolases, and the subclass 3.4 , the peptide hydrolases or peptidases. The term "peptidase" is recommended by the Nomenclature Committee of International Union of Biochemistry and Molecular Biology to be used as synonymous with "peptide hydrolase" for any of the enzyme that hydrolyzes peptide bonds $[1,3]$.

However, proteases do not act in accordance with the universal enzyme nomenclature system due to their high structural diversity and specificity. At present, proteases are classified depending on three major criteria: (i) type of reaction catalyzed, (ii) chemical nature of the catalytic site, and (iii) evolutionary relationship with reference to structure [1]. Currently, the term "peptidase" is also used equivalently with "protease" and "proteinase." Peptidase was restricted to the enzymes included in subsubclasses EC 3.4.11-19, the exopeptidases in the Enzyme Nomenclature (1984), while the term "proteinases" was previously used for the enzymes included in subsubclasses EC 3.4.21-99 having the same meaning as "endopeptidase." However, the terms "protease" and "proteinase" are still preferred by many scientists [3].

1.1. Classification of Protease. Proteases are generally categorized into two major groups based on their site of action, that is, exopeptidases and endopeptidases. Exopeptidases are those proteases that cleave the peptide bond proximal to the amino or carboxy termini of the substrate (cleave $\mathrm{N}$ - or C-terminal peptide bonds of a polypeptide chain), whereas endopeptidases cleave peptide bonds distant from the termini of the substrate (cleave internal peptide bonds) [3, 4]. Proteases are also classified into acid, alkaline, and neutral proteases based on the $\mathrm{pH}$ at which they are active [1].

On the basis of their catalytic action, protease has been also grouped into four categories as aspartic, cysteine, metallo, and serine proteases. However, recently, three new systems have been defined: the threonine-based proteasome system, the glutamate-glutamine system of eqolisin, and the serine-glutamate-aspartate system of sedolisin [2].

1.1.1. Serine Proteases. Serine proteases (EC 3.4.21) are described by having a serine group in their active site. They are abundant and common among viruses, bacteria, and eukaryotes, indicating that they are useful for the organisms. Serine proteases are found in the exopeptidase, endopeptidase, oligopeptidase, and omegapeptidase groups $[4,5]$. Most of the neutral and alkaline protease that are commercial serine proteases are produced from bacteria of the genus Bacillus. Similar serine enzymes can also be produced from other bacteria, such as Thermus caldophilus and Desulfurococcus mucosus, Streptomyces, Aeromonas, and Escherichia. Fungi species like Aspergillus oryzae similarly produce several serine proteases [1] (Table 1).

1.1.2. Cysteine/Thiol Proteases. Cysteine proteases (EC 3.4.22) occur in both prokaryotes and eukaryotes [4, 5]. There are about 20 families of cysteine proteases. The activity of all cysteine proteases was determined on a catalytic dyad consisting of cysteine and histidine. The order of Cys and His (Cys-His or His-Cys) residues varies among the families. Generally, cysteine proteases are active only in the presence of reducing agents, such as $\mathrm{HCN}$ or cysteine. Cysteine proteases are broadly categorized into four groups based on the specificity of their side chain: (i) papain like, (ii) trypsin like with preference for cleavage at the arginine residue, (iii) specific to glutamic acid, and (iv) others. Papain cysteine proteases have optimum activity at neutral $\mathrm{pH}$, while a few of them like lysosomal proteases have maximum activity at acidic $\mathrm{pH}$. They are sensitive to sulfhydryl agents such as PCMB but are not affected by DFP and metal-chelating agents [4]. Cysteine proteases are not so broadly distributed as was seen with serine and aspartic proteinases [1] (Table 1).

1.1.3. Aspartic Proteases. Aspartic proteinases (EC 3.4.23) or aspartyl proteinases are endopeptidases having two aspartic acid residues (Asp32 and Asp215, pepsin numbering) within their active site that are vital for their catalytic activity [7]. It is commonly known as acidic proteases [4].

Acidic proteases have been categorized into three families, that is, pepsin (A1), retropepsin (A2), and enzymes from pararetroviruses (A3). They have been placed in clan AA. Most of the aspartic proteases (Aps) show the best activity at low $\mathrm{pH}$ ( $\mathrm{pH} 3$ to 4 ) and have isoelectric points in the $\mathrm{pH}$ range of 3 to 4.5 [4]. They are inhibited by a hexapeptide from Streptomyces that contains two statin residues called pepstatin. Aspartic proteases are also sensitive to diazoacetyl-DL-norleucine methyl ester (DAN) and 1, 2-epoxy-3-(p-nitrophenoxy) propane (EPNP) in the presence of copper ions. Microbial acid proteases exhibit specificity against aromatic or bulky amino acid residues on both sides of the peptide bond, which is similar to pepsin, but their action is less stringent than that of pepsin $[4,7]$.

Acid proteases represent an essential group of enzymes, extensively used in food, beverage, and pharmaceutical industries. For most of these applications, the crude enzymes should at least partially purified and free from substances that could alter the characteristics of the product [8].

Aspartic protease enzymes from microbial sources are mainly categorized into two groups: (i) the pepsin-like enzymes produced by Aspergillus, Penicillium, Rhizopus, and Neurospora and (ii) the rennin-like enzymes produced by Endothia and Mucor spp., such as Mucor miehei, M. pusillus, and Endothia parasitica [4, 6] (Tables 1 and 2).

1.1.4. Metalloproteases. Metalloproteases (EC 3.4.24) are highly diversified types of proteases. They contain enzymes 
TABLE 1: The characteristics of four types of protease [6].

\begin{tabular}{|c|c|c|c|c|c|c|c|c|}
\hline Properties & $\begin{array}{c}\text { EC } \\
\text { number }\end{array}$ & $\begin{array}{l}\text { Molar } \\
\text { mass } \\
\text { range } \\
(\mathrm{kDa})\end{array}$ & $\underset{\text { optimum }}{\mathrm{pH}}$ & $\begin{array}{c}\text { Temperature } \\
\text { optimum }\end{array}$ & $\begin{array}{l}\text { Metal } \\
\text { requirement } \\
\text { (s) }\end{array}$ & $\begin{array}{l}\text { Active amino } \\
\operatorname{acid}(\mathrm{s})\end{array}$ & Major inhibitor(s) & Major sources \\
\hline $\begin{array}{l}\text { Aspartyl or } \\
\text { carboxyl } \\
\text { protease }\end{array}$ & 3.4 .23 & $30-45$ & $3-5$ & $40-55$ & $\mathrm{Ca}^{2+}$ & $\begin{array}{l}\text { Aspartate or } \\
\text { cysteine }\end{array}$ & Pepstatin & $\begin{array}{l}\text { Aspergillus, Mucor, } \\
\text { Endothia, Rhizopus, } \\
\text { Pencillium, } \\
\text { Neurospora, animal } \\
\text { tissue (stomach) }\end{array}$ \\
\hline $\begin{array}{l}\text { Cysteine or } \\
\text { thiol protease }\end{array}$ & 3.4 .22 & $34-35$ & $2-3$ & $40-55$ & - & $\begin{array}{l}\text { Aspartate or } \\
\text { cysteine }\end{array}$ & $\begin{array}{c}\text { Iodoacetamide, } \\
p \text {-CMB }\end{array}$ & $\begin{array}{c}\text { Aspergillus, stem of } \\
\text { pineapple (Ananas } \\
\text { comosus), latex of } \\
\text { fig tree (Ficus sp), } \\
\text { papaya (Carica } \\
\text { papaya), } \\
\text { Streptococcus, } \\
\text { Clostridium }\end{array}$ \\
\hline Metalloprotease & 3.4 .24 & $19-37$ & $5-7$ & $65-85$ & $\mathrm{Zn}^{2+}, \mathrm{Ca}^{2+}$ & $\begin{array}{c}\text { Phenylalanine } \\
\text { or leucine }\end{array}$ & $\begin{array}{c}\text { Chelating agents } \\
\text { such as EDTA and } \\
\text { EGTA }\end{array}$ & $\begin{array}{c}\text { Bacillus, } \\
\text { Aspergillus, } \\
\text { Pencillium, } \\
\text { Pseudomonas, } \\
\text { Streptomyces }\end{array}$ \\
\hline Serine protease & 3.4 .21 & $18-35$ & $6-11$ & $50-70$ & $\mathrm{Ca}^{2+}$ & $\begin{array}{c}\text { Serine, } \\
\text { histidine, and } \\
\text { aspartate }\end{array}$ & $\begin{array}{l}\text { PMSF, DIFP, } \\
\text { EDTA, soybean } \\
\text { trypsin inhibitor, } \\
\text { phosphate buffers, } \\
\text { indole, phenol, and } \\
\text { triamino acetic acid }\end{array}$ & $\begin{array}{c}\text { Bacillus, } \\
\text { Aspergillus, animal } \\
\text { tissue (gut), } \\
\text { Tritirachium album } \\
\text { (thermostable) }\end{array}$ \\
\hline
\end{tabular}

from different origins, such as collagenases from higher organisms, hemorrhagic toxins from snake venoms, and thermolysin from bacteria. For their actions, they require divalent metal ion. A total of about 30 families of metalloproteases have been documented, out of which 17 contain only endopeptidases, 12 contain only exopeptidases, and 1 (M3) contains both endo- and exopeptidases [4,5] (Table 1).

\subsection{Mechanism of Action of Aspartic Protease. Aspartic} proteases (EC 3.4.23) are peptidases that exhibit various activities and specificities. They are found in animals, plants, fungi, and viruses. Aspartic proteases (Aps) have been connected to a wide range of physiological functions, including mammalian digestion of nutrients (e.g., chymosin and pepsin A), defense against pathogens, yeast virulence (e.g., candidapepsins), metastasis of breast cancer (e.g., cathepsin D), pollen-pistil interactions (e.g., cardosin A), control of blood pressure (e.g., renin), degradation of hemoglobin by parasites (e.g., plasmepsins), and maturation of HIV proteins (retropepsin) [11].

Aspartic proteases (Aps) belong to the A1 pepsin family structurally. They are synthesized as preproenzymes similar to other pepsin enzymes. The proenzyme is secreted and autocatalytically activated after cleavage of the signal peptide. Commonly, the active enzymes contain a single peptide chain of about 320-360 amino acid residues with a molecular mass of $32-36 \mathrm{kDa}$. Aps mostly have a $\beta$-strand secondary structure arranged in a bilobal conformation as confirmed by X-ray crystallographic analyses [11]. The two lobes are homologous to each other and have evolved by gene duplication. The catalytic center is located between the two lobes and contains a pair of aspartate residues, one in each lobe, that are essential for the catalytic activity [11]. The retropepsin molecule has only one lobe, which consists of only one aspartic residue, and the activity requires the formation of a noncovalent homodimer [4]. Generally, aspartic endopeptidases depend on its aspartic acid residues for their catalytic activity [4].

In pepsin family enzymes, the catalytic Asp residues are mostly contained in an Asp-Thr- $X$ motif, where $X$ is Ser or Thr. The role of these Asp residues is to activate a water molecule that facilitates the nucleophilic attack on peptide bond of the substrate and also to find another water molecule that is used in substrate binding by the formation of hydrogen bond. The catalytic center is enough to accommodate as a minimum of seven residues of the polypeptide substrate. A flexible structure (flap) found at the entry of the catalytic site controls the specificity of the enzyme [11]. APs are mostly active at acidic $\mathrm{pH}$. The optimum $\mathrm{pH}$ of aspartic protease is determined by the electrostatic potential at the active site, which in turn is determined by the position and orientation of all residues near the active site [11] (Table 2).

\section{Microbial Source of Aspartic Protease}

The failure of the plant and animal proteases to meet the present world demands of the enzyme has directed to an increased interest in microbial proteases. The presence of desired characteristics for biotechnological applications in microbial protease enzymes helps it to be preferred over 


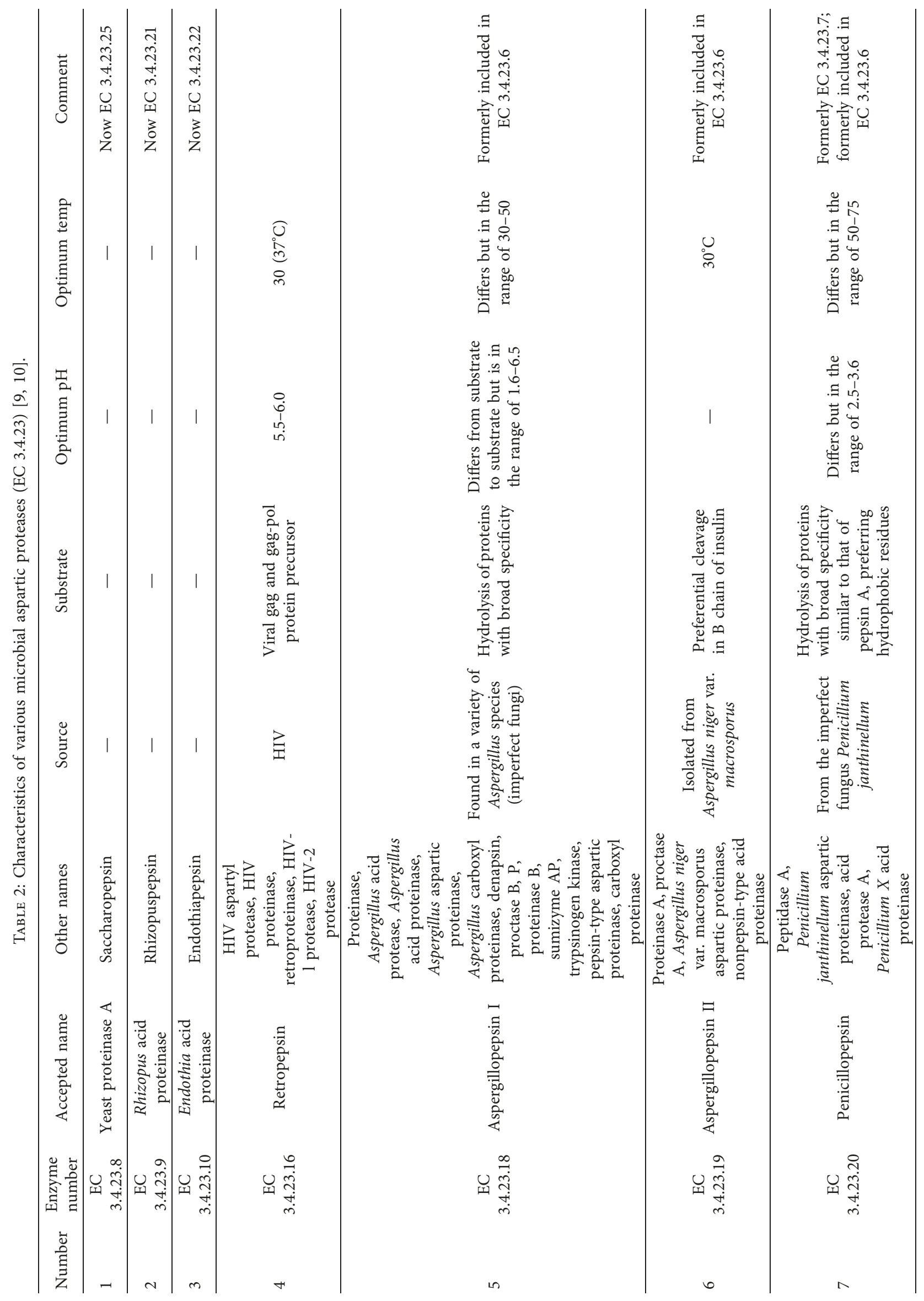




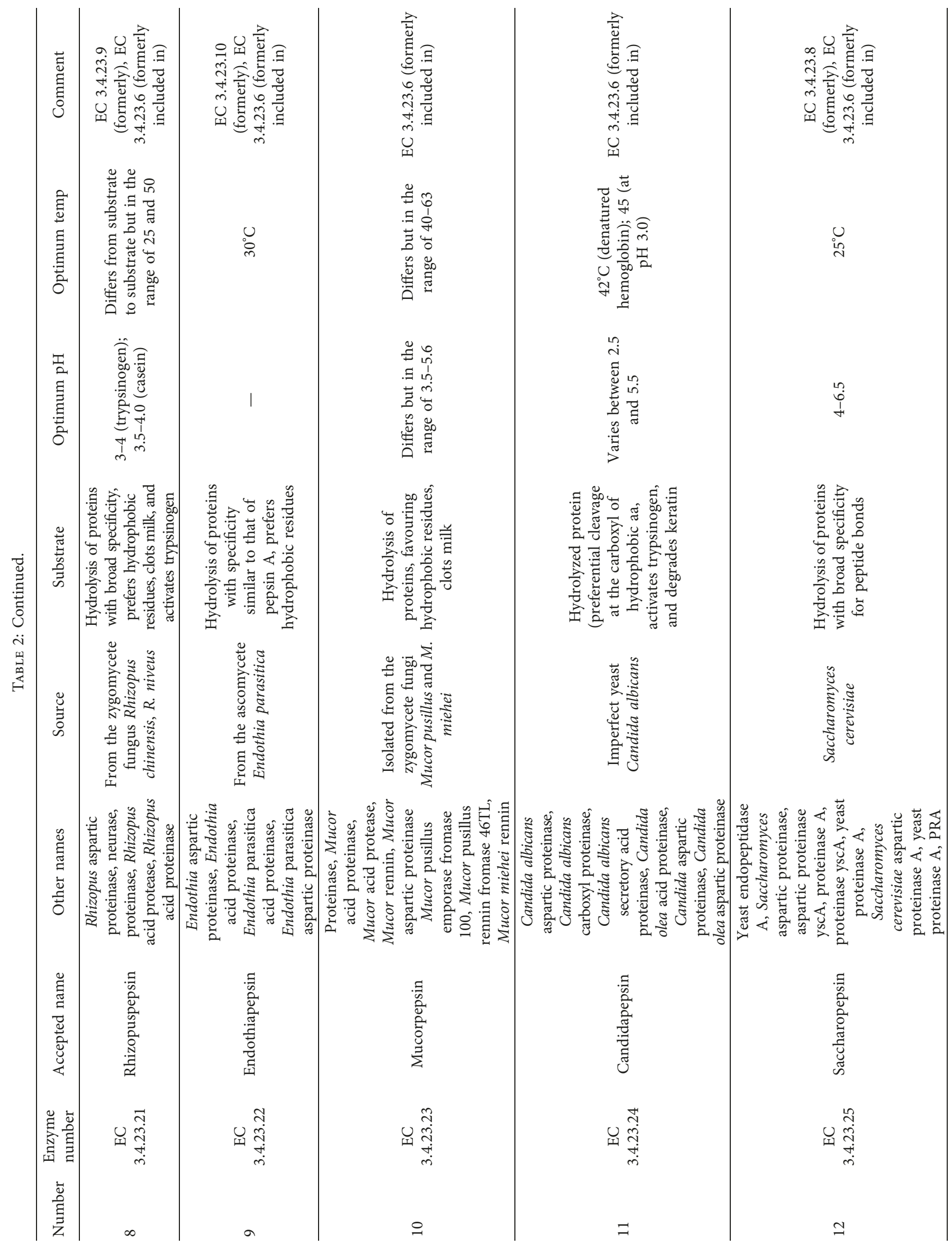




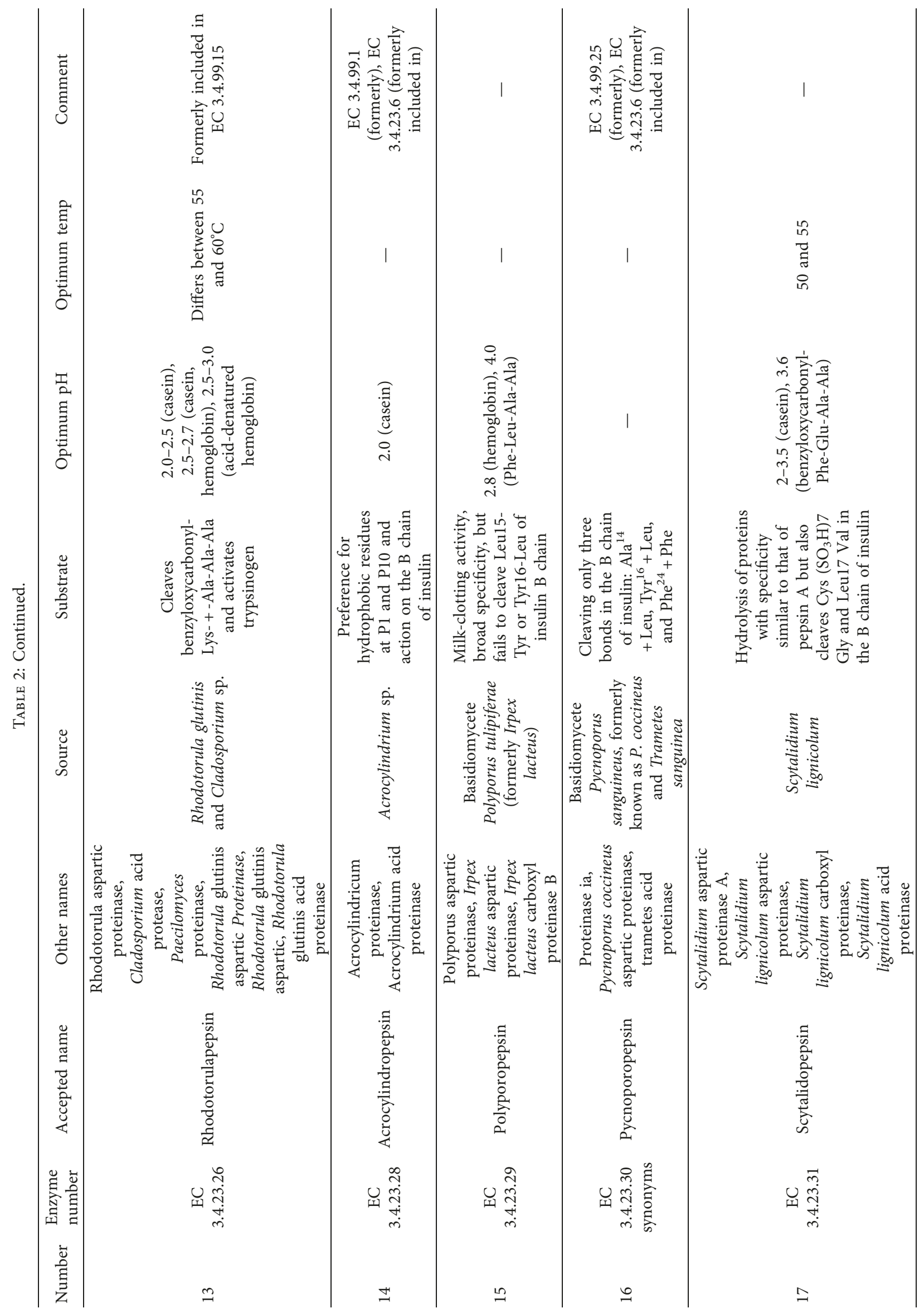




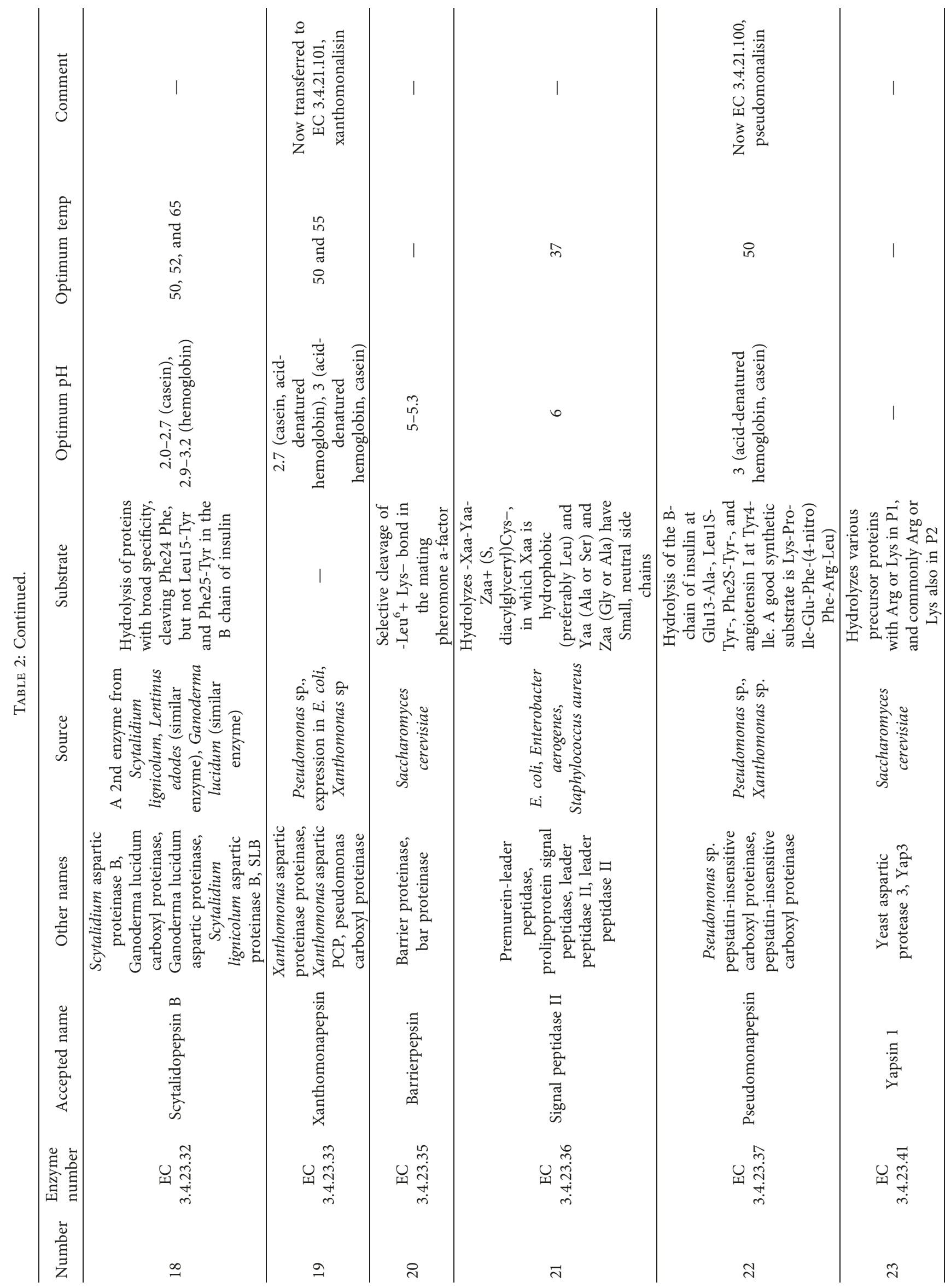




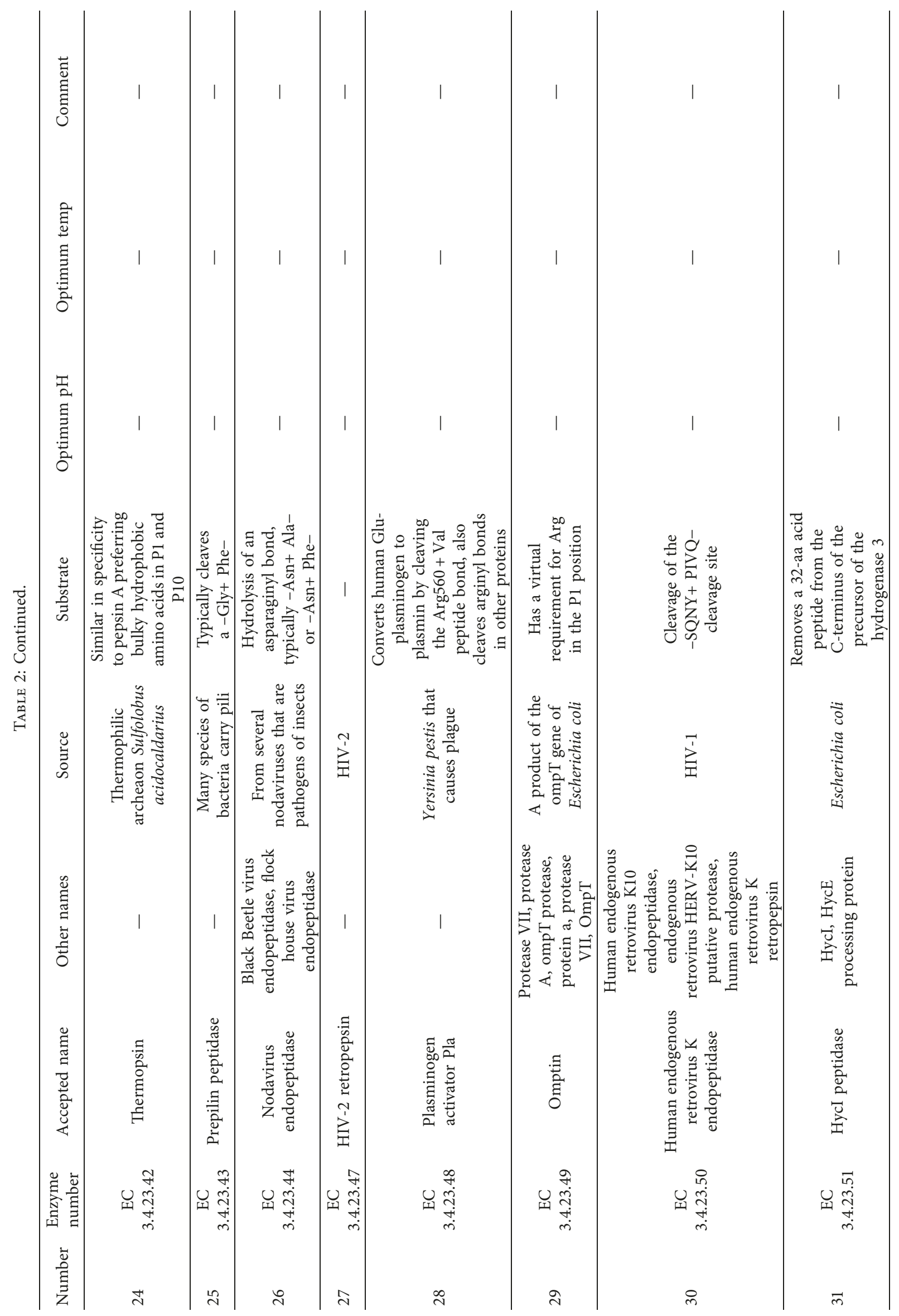


TABle 3: Microbial sources of milk-clotting aspartic proteases [13].

\begin{tabular}{lr}
\hline Microorganisms & Properties \\
\hline Pleurotus sojur-caju (white rot fungi) & Clotting activity under cheese-making conditions \\
\hline Mucor bacilliformis & $\begin{array}{c}\text { High structural similarity to bovine chymosin lower } \\
\text { thermostablity than Rhizomucor miehei protease }\end{array}$ \\
\hline Thermoascus aurantiacus & $\begin{array}{c}\text { Enzymatic hydrolysis of bovine casein differed largely } \\
\text { from proteolysis patterns generated by bovine chymosin }\end{array}$ \\
\hline Thermomucor indicae-seudaticae N31 & $\begin{array}{r}\text { Crude enzymatic extract showed high milk-clotting } \\
\text { and low proteolytic activity and low thermostability }\end{array}$ \\
\hline Metschnikowia reukaufii & $\begin{array}{r}\text { Milk-clotting activity, successfully cloned into } \\
\text { Escherichia coli }\end{array}$ \\
\hline Myxococcus xanthus & $\begin{array}{r}\text { Molecular mass: } 40 \text { kDa, highest clotting activity at } \\
\text { pH } 6 \text { and } 37^{\circ} \text { C, acceptable yield and properties of the } \\
\text { curd in cheese-making experiments, successfully } \\
\text { cloned into Escherichia coli }\end{array}$ \\
\hline Enterococcus faecalis & $\begin{array}{r}\text { Similar electrophoretic patterns of hydrolyzed } \\
\text { k-casein as Rhizomucor miehei, effectively applied for } \\
\text { camembert cheese manufacture }\end{array}$ \\
\hline Nocardiopsis sp. & $\begin{array}{c}\text { Milk-clotting ability of extracellular extracts, optimization } \\
\text { of enzyme yield by fermentation conditions }\end{array}$ \\
\hline Bacillus subtilis & $\begin{array}{r}\text { Ratio of milk clotting to proteolytic activity is } \\
\text { comparable with commercial fungal protease but has } \\
\text { high thermostability }\end{array}$ \\
\hline Bacillus licheniformis & Shows typical milk-clotting kinetics \\
\hline
\end{tabular}

plant and animal proteases. Microorganisms represent an excellent source of enzymes owing to their wide biochemical diversity and their susceptibility to genetic manipulation. About $40 \%$ of the total global enzyme sales are from microbial sources [4]. Aspartic protease is found in molds and yeasts, but rarely in bacteria [6].

2.1. Fungal Aspartic Proteases. Fungi produce a wider range of enzymes than do bacteria. For instance, Aspergillus oryzae produces all types of proteases such as acid, neutral, and alkaline proteases. The $\mathrm{pH}$ ranges ( $\mathrm{pH} 4$ to 11 ) of fungi protease are wide, and this shows their broad substrate specificity. However, they have a lower reaction rate and low heat tolerance than do the bacterial enzymes. Fungal enzymes can be conveniently produced in a solid-state fermentation process [4].

Due to the global scarcity of calf chymosin, fungal aspartic proteases (Aps) have been used as milk-clotting enzymes in the dairy industry for about 30 years. The aspartic protease enzymes produced from Mucor miehei, Mucor pusillus, and Cryphonectria (Endothia) parasitica and marketed under the trade names Rennilase ${ }^{\circledR}$, Fromase ${ }^{\circledR}$, Novoren ${ }^{\circledR}$, Marzyme $^{\circledR}$, Hannilase $^{\circledR}$, Marzyme $^{\circledR}$, and Suparen ${ }^{\circledR}$ are usually used for the production of various types of cheeses [11]. The production of aspartic acid proteases that have a certain industrial application was also reported from Botrytis cinerea [12]. An alternative for milk clotting enzyme for cheese production was also reported from more than 100 fungal sources. Fungi that produce milk clotting enzyme are universal and easily isolated from various environments [13].

Most of these extracellular fungal aspartic proteases produced from Aspergillus species. These include Aspergillus oryzae, Aspergillus fumigatus, Aspergillus saitoi, Aspergillus awamori, and Aspergillus niger [5]. Aspartic proteases from Candida albicans have been intensively studied due to its role in various forms of candidiasis. The presence of secreted aspartic protease enzyme in $C$. albicans contributes to its virulence factor. The major proteases secreted in vitro by C. albicans, C. parapsilosis, and C. tropicalis have been termed as Sap2, Sapp1, and Sapt1, respectively [5].

A different study has revealed that $C$. albicans have at least eight secreted aspartic protease genes (SAP genes). Out of these, SAP2 gene is the leading form expressed in a number of strains. SAP2 encodes 398-residue preproprotein that is processed to a 342-residue mature enzyme, a typical aspartic proteinase having an optimum $\mathrm{pH}$ between 3 and 4 and inhibited by pepstatin A [14]. The optimum $\mathrm{pH}$ for fungal aspartic proteases is between 4 and 4.5; however, they are stable at a $\mathrm{pH}$ range between 2.5 and 6.0. Fungal aspartic protease enzymes are specifically useful in the cheese-making industry due to their narrow $\mathrm{pH}$ and temperature specificities [4] (Tables 2 and 3).

2.2. Bacteria. It has been widely assumed that bacteria do not produce clotting enzymes due to only a few research works conducted on bacteria [15]. But the study conducted on the genomes of two bacteria, Escherichia coli and Haemophilus influenzae, showed that the recombinant proteins resulting from the expression of each of these DNA regions are active aspartic proteinases [15].

A novel retropepsin-like enzyme (APRc) has been also found in two pathogenic species of Rickettsia such as $R$. conorii and $R$. rickettsia. This APRc enzyme is particularly inhibited by drugs clinically used to treat HIV infections, and therefore, this enzyme can be used as a target for 
therapeutic intervention. This implies that a retropepsin type of aspartic protease enzymes is found in prokaryotes, signifying that these enzymes may represent an ancestral form of these proteases [16]. Acid protease produced by Bacillus subtilis, which is GRAS (genetically regarded as safe), is gradually replacing chymosin in cheese making, and protease produced from $B$. subtilis var. natto has showed milk clotting [4, 17]. Microbial aspartic protease produced from Bacillus amyloliquefaciens was also used for the production of miniature cheddar-type cheeses [18] (Tables 2 and 3).

2.3. Viruses. The concern to viral proteases has been started as a result of its involvement in the cause of certain fatal diseases, such as AIDS and cancer. Several types of viruses have serine, aspartic, and cysteine peptidases. All of the virus-encoded peptidases are endopeptidases, but there are no metallopeptidases in viruses [4]. The crystal structures of aspartic proteases from retroviruses such as HIV and Rous sarcoma have been widely studied and determined since 1989 [5]. The aspartyl proteases of retroviruses have a great role in viral assembly and replication. The aspartyl proteases of retroviruses are homodimers and expressed as a part of the polyprotein precursor. The mature protease is released by autolysis of the precursor [4].

Microbes serve as an ideal source of protease enzymes, even though they are widespread in nature. The rapid growth, the lesser space required for cultivation, and the ease for genetic manipulation to generate new enzymes with improved properties make microbes desirable for protease enzyme production [4] (Table 2).

\section{Application of Microbial Aspartic Protease}

The proteases have been considered as one of the most essential groups of enzymes in enzyme industry and have various applications in different industries, such as detergents, foods, pharmaceuticals, and leather [19].

Microbial acid proteases have an application mostly in three industries: food, beverage, and pharmaceuticals [5]. However, there is limited evidence available on the application of aspartic proteinases other than cheese industry that has been the preferred area of application to date [7].

3.1. Application in Dairy Industry. The major application of acid proteases is for cheese production in dairy industry. The microbial milk-coagulating proteases belong to a class of acid aspartate proteases and have molecular weights between 30,000 and 40,000 [4]. The major role of acid proteases in cheese production is to hydrolyze the specific peptide bond (the Phe105-Met106 bond) to generate para-K-casein and macropeptides. Chymosin is preferred due to its high specificity for casein, which accounts for its exceptional performance in cheese production. The aspartic proteases produced by microbes such as Mucor miehei, B. subtilis, and Endothia parasitica, which is GRAS (genetically regarded as safe), are gradually replacing chymosin in cheese making [4].

The enzymatic coagulation of milk is a two-phase process; any variation in the chemical environment can affect the two phases of reaction separately [7]. In the first phase, calf rennet (CAR) and most microbial proteases clot milk with the cleavage of $\mathrm{K}$-casein at the Phenylalanine105Methionine 106 bond, which liberates hydrophilic glycopeptide (residues 106-169) that enters into the whey and para-K-casein (hydrophobic) [7, 20]. Proteinase from Cryphonectria parasitica cleaves the S104-F105 bond. Rennin can also hydrolyze other milk proteins ( $\alpha$ s1-, $\alpha \mathrm{s} 2-$, and $\beta$-caseins and $\alpha$-lactalbumin) at a lower rate. Fungal proteases cause extensive nonspecific hydrolysis of both $\mathrm{K}$-casein and para-K-casein as compared to rennin in which its activity is limited to the hydrolysis of K-casein with the formation of only macropeptide and para-K-casein [20].

The second phase is nonenzymatic in which para-Kcasein and other caseins aggregate under the influence of $\mathrm{Ca} 2+$, which eventually leads to gel formation. These two steps of milk-clotting activity overlap with each other where the aggregation of micelles starts before the end of the enzymatic process [20].

The production of UF (ultrafiltrated) white soft cheese using fungal rennin ( $1 \mathrm{ml}$ fungal rennin/100 $\mathrm{ml} \mathrm{milk)} \mathrm{from}$ Rhizomucor miehei NRRL 2034 in the laboratory showed very close properties to calf rennet cheese used as a control. The cheese produced with fungal rennet revealed better values of soluble nitrogen $(\mathrm{SN})$, total volatile fatty acids (TVFAs), tyrosine, and tryptophan than control cheese. Moreover, the sensorial examination conducted on cheese produced with fungal rennet showed that the experimental cheese had a soft body, smooth texture, and desirable taste during cold storage for 2 months [21, 22].

The production of miniature cheddar-type cheeses using microbial rennet from Bacillus amyloliquefaciens (clotting enzyme (MCE)) and calf rennet (CAR) did not have significant differences in gross composition with the exception of $\mathrm{pH}$. The level of $\alpha$ s1-casein and $\beta$-casein hydrolysis determined by urea-PAGE was equivalent for both cheese samples. The concentration of peptides in 2 cheese samples was increased during the course of ripening. However, the ratio of hydrophobic to hydrophilic peptides was higher in $\mathrm{CAR}-\mathrm{C}$ than in MCE-C. The MCE-C was softer than CAR-C as a result of higher protein hydrolysis. Microbial rennet from B. amyloliquefaciens contributed to higher photolytic rates that reduced ripening time [18].

In the study that compares the milk-clotting activity of proteinase produced by B. subtilis var. natto, Rhizopus oligosporus, and commercial rennet, the curd formed by the commercial rennet had the highest viscosity and curd tension and the shortest clotting time followed by the curd produced by proteinase from Rhizopus among the three enzymes. The highest proteolytic activity was recorded by the enzymes from $B$. subtilis, while the highest milk-clotting enzymes were noticed in commercial rennet. Observations of microstructures by scanning electron microscope (SEM) showed that the three-dimensional network of curd formed by commercial rennet was denser, firmer, and smoother than others [17]. Fresh cheese produced using an ochratoxin-free extracellular acid protease from Aspergillus niger FFB1 and reconstituted cow milk as a substrate showed similar basic characteristics $(\mathrm{pH} 4.5$, acid taste, and white 
color) as cheeses produced with calf rennet [23]. The concentration of free amino acid (FAA) and physiochemical characteristics were similar in the Turkish, white, brined cheese produced using calf rennet and microbial rennet from Rhizomucor miehei [24].

The experimental study conducted on cheese produced by calf rennet and microbial rennet from Rhizomucor miehei after 90 days of ripening period revealed that the physicochemical characteristics and the contents of the total bitter tasting amino acids (Phe, Leu-Ile, Val, and Pro) were similar for both types of cheeses. Phe, Leu-Ile, Gln, Val, Pro, and Ala were the principal free amino acids (FAAs) in the white cheeses at all stages of ripening [25].

The study during 2 months under pickling conditions of domiati cheese produced using the M. mucedo KP736529 enzyme (E-cheese) and commercial calf rennet (C-cheese) as control showed that the yield and chemical properties of E-cheese were better than those of C-cheese. The fungal enzyme (MCE) showed higher proteolytic activity than calf rennet with the absence of bitter taste defects. The organoleptic scores of E-cheese were also higher than C-cheese [26].

In the study conducted at Hyderabad, the milk-clotting enzyme produced from Rhizomucor miehei was subjected to ammonium sulfate and acetone precipitation and then used for cheese production. The result indicates that higher quantity of cheese $(280 \mathrm{~g} / 500 \mathrm{ml}$ milk) was obtained by ammonium sulfate precipitation than with acetone precipitation $(220 \mathrm{~g} / 500 \mathrm{ml}$ milk). But the milk curdling time was found to be rapid with the enzyme obtained by acetone precipitation than that obtained by saturated ammonium sulfate precipitation [27].

3.2. Application in the Bakery Industry. Wheat flour is a major component of baking processes. It comprises an insoluble protein called "gluten" that regulates the dough property. Endo and exoproteinases from Aspergillus oryzae have been applied to improve the wheat gluten by limited proteolysis [4]. Moreover, fungal aspartic proteases have also been broadly used in the production of food seasonings and the improvement of protein-rich foods such as bread and related foodstuffs [5].

The fermentation of liquid dough made from wheat flour with the combination of enterococci and Rhizopus oryzae proteases (dough B) for $48 \mathrm{~h}$ revealed that it had threefold higher concentration of water-soluble peptides than the chemically acidified dough (CAD) used as the control. The concentration of free amino acids was also being higher in dough B. The SDS-PAGE analysis showed that gliadins were almost fully degraded in dough B, while albumin and glutenin fractions were incompletely hydrolyzed [28]. In another study, gluten treated with pepsin had shown a band less than $10 \mathrm{kDa}$, while gluten treated with pronase, chymotrypsin, and papain showed two bands corresponding to 40 and $10 \mathrm{kDa}$ by HPLC analysis. These results suggest that less protease-resistant peptides exist in gluten treated with pepsin as compared to gluten treated with pronase, chymotrypsin, and papain [29].

The experimental gluten-free pasta (E-GFp) produced from gluten-free sourdough after fermentation by lactic acid bacteria and fungal proteases showed higher chemical scores, essential amino acid profile, biological value, and nutritional index than those of durum wheat pasta (CDWp). This might be due to proteolysis during sourdough fermentation. The in vitro protein digestibility of E-GFp has also resulted in the highest value. The sensory characteristic of E-GFp was acceptable as shown by sensory analysis [30].

The hydrolysis of wheat gluten by the acid protease from Aspergillus usamii under optimized conditions has greatly increased the solubility of wheat gluten. Enzymatic hydrolysis of wheat gluten resulted in a radical increase in emulsifying activity index (EAI), water, and oil-holding capacity. The molecular weight determination study also showed that most of the peptides above $10 \mathrm{kDa}$ have been hydrolyzed into smaller peptides. Furthermore, the functional properties of wheat gluten improved after hydrolysis [31].

The treatment of nine immunogenic epitopes of the 26mer and 33-mer gliadin fragments by prolyl endopeptidase from Aspergillus niger (AN-PEP) successfully degraded all the nine epitopes in the stomach $\mathrm{pH}$ range at considerable lesser dosage than the digestive enzyme supplements. The digestive enzyme supplements showed comparable proteolytic activities with near neutral $\mathrm{pH}$ optima and modest gluten detoxification properties as determined by ELISA [32].

3.3. Application in the Beer Industry. The visual aspects of beer such as clarity, color, and foam are vital for consumers. Foam affects the consumers' views, flavor, and mouth feel about the beer. Brewers desire the presence of sufficient, stable, white, and finely textured foam to satisfy consumers' concern [33].

Haze formation is a major problem in beer production, as it affects the qualities of the end product [34]. During the production of beer, proteins and polyphenols extracted from the plant tissue may interact and form haze [35]. Beer haze comprises numerous components: the most common organic parts are proteins (40-75\%), polyphenols (in combination with proteins), and, to a smaller percentage, carbohydrate (2-15\%) [34]. The group of proteins that contributes to haze formation is called "cystine-rich proteoses" (albumins and barley hordeins) [36].

There are two types of haze: the cold break (chill haze) and the age-related haze. The cold break haze is formed at $0^{\circ} \mathrm{C}$ and disappears at higher temperatures. If cold break haze does not dissolve, age-related haze, which is irreversible, develops. Chill haze is produced after polypeptides and polyphenols bound noncovalently. Permanent haze is produced in a similar way primarily, but covalent bonds are soon formed and insoluble complexes are created that will not dissolve when heated [34]. Both chill haze and agerelated haze formation are not desired by the consumers, as they show the oldness and staleness of beer and alter the physical stability of beer $[36,37]$.

The production of undesirable chill haze in the final beer product can be removed by several ways. These include hydrolyzing the undesirable proteins in finishing the operation, adsorbing proteins using silica adsorbents or silica 
hydrogels, and/or using polyvinylpolypyrrolidone to remove polyphenols that contribute to protein condensation reactions [36]. The application of proline-specific endoproteinases (i.e., Brewers Clarex ${ }^{\circledR}$, DSM, France) that target on the degradation of haze-active proteins (i.e., hordeins) reduces the formation of storage haze in final beer product. These hydrolyzed proteins are unable to condense with polyphenols and hence do not form haze [37]. The addition of a brewer's yeast that secretes a proteinase enzyme that can degrade haze-forming proteins into brewer's wort during wort fermentation is also a possible alternative to remove chill-proofing beer [36].

The addition of acid proteinase from Saccharomycopsis fibuligera 1570 and Torulopsis magnoliae 1536 along with brewer's yeast into brewer's wort in bench-scale fermentations conducted at $200^{\circ} \mathrm{C}$ showed that the final bottled beer was resistant to haze formation with a slight reduction in the final ethanol concentration [36]. The addition of proteinase A $(0.5 \mathrm{mU} / \mathrm{ml}$ concentration $)$ to the sweet wort and incubating for $144 \mathrm{~h}$ at $250^{\circ} \mathrm{C}$ also showed a significant decrease in hydrophobic character of wort. Moreover, the activity of proteinase A contributed for about $47 \%$ reduction in hydrophobic nature of high gravity sweet wort. This result implies that proteinase A alters the hydrophobic character rather than the molecular size of the wort polypeptide [34]. Similarly, the use of commercial protease enzyme from Bacillus subtilis correspondingly increased the level of total soluble nitrogen, levels of $\alpha$-amino nitrogen, wort color, and extract recovery levels in wort when mashing with $100 \%$ raw barley malt. However, as the level of protease increased, the efficiency of the protease decreased [38].

The incubation of beer wort with acidic proline-specific protease from Aspergillus niger in small-scale brewing experiment extensively hydrolyzed the proline-rich proteins and produced a peptide fraction unable to form a haze. Subsequent pilot plant trials also verified that the addition of this acidic enzyme even at low levels during wort fermentation efficiently inhibits chill haze formation in bottled beer. Results from the determination of beer foam stability indicated that the enzyme treatment did not affect the beer foam [35].

The addition of protease enzyme during beer fermentation also has a significant benefit beyond haze removal. The expression of aspartyl protease in recombinant yeast used for fuel ethanol production improves the capability of the yeast to metabolize soluble proteins and leads to significant increase in ethanol production. Furthermore, the recombinant yeast strains exhibited advanced growth rate, viability, and lower yields of by-products such as glycerol and pyruvic acid [39]. Likewise, the use of the multicomponent protease enzyme (Flavourzyme) with brewer's yeast strain Weihenstephan 34/70 for beer fermentation showed a significant increase in nitrogen availability during the course of beer fermentation [40].

3.4. Application in Wine Industry. The production of clear wine, particularly for white wines, is one of the very important parameters from the consumer's perspective. Therefore, maintaining the stability of wine before bottling is a challenging and crucial step in the winemaking process.
A stable white wine is a clear wine that is free from any precipitates at the time of bottling till to consumption. Hazy wine with precipitate is formed as a result of microbial instability, tartrate instability, and protein heat instability [41]. Microbial stability is attained prior to bottling by the addition of sulfur dioxide and filtration, whereas tartrate stability is accomplished by three techniques, such as cold stabilization, ion exchange resins, and/or electrodialysis [41].

Heat unstable grape protein could remain and cause hazy appearance in final wine products. Grape proteins in wines that exist as unstable under certain conditions can aggregate into light-dispersing particles and cause wines to appear turbid. Specifically, grape pathogenesis-related (PR) proteins, such as thaumatin-like proteins (TLPs) and chitinases, contribute for wine haze formation [42]. Other proteins like $\beta$-glucanases have also been associated with haze formation, while they are much less abundant than chitinases and TLPs in wine. But the role of $\beta$-glucanases in wine haze formation is not widely studied [41].

The mechanism of haze formation is started by the unfolding and aggregation of grape-derived wine proteins. The experimental study proved that wine protein unfolding and aggregation are the two discrete events occurred in wine processing. Heat experiment has shown that proteins can unfold as soon as the wine is heated, while haze is formed after wine cooling [41].

In commercial winemaking, the stability of proteins is accomplished by the addition of bentonite. Bentonite is a clay cation exchanger that binds with proteins and eliminates them from wine through precipitation, and it has been commonly used in oenology as a fining agent since the 1930s [41, 42]. Proteins that bound with bentonite settle to the bottom of wine tanks as lees, and it covers $3-10 \%$ of the total wine volume. Wine is recovered from bentonite lees using rotary drum vacuum filtration, specialized lees filtration equipment, or centrifugation processes [41]. Bentonite fining has some negative characteristics such as dilution of the wine by the bentonite slurry, elimination of wine flavor, high labor expenses, trouble in bentonite spent disposal, and loss of wine quality [42].

For the abovementioned reasons, alternative methods for stabilizing white wine have been extensively studied $[41,42]$. Several alternatives have been suggested, like the use of other adsorbents, ultrafiltration, and flash pasteurization, but none of them has proven suitably effective to replace bentonite. One ideal solution to this issue would be the use proteolytic enzymes capable to degrade the heat unstable proteins [42].

Acid protease enzyme is suitable for the degradation of the turbidity complex produced from proteins in fruit juices and alcoholic liquors [6]. Some fungal aspartic proteases have been used to hydrolyze proteins that cause turbidity in juices and wine. These are the protease BcAP8 from Botrytis cinerea and the aspergillopepsin I from Aspergillus saitoi (commercially marketed as Molsin F by Kikkoman Corp., Japan), both used in the winery as they successfully remove haze-forming proteins and hence reducing bentonite requirements [19]. The addition of AGP (a combination of Aspergillopepsin I (EC 3.4.23.18) and Aspergillopepsin II 
(EC 3.4.23.19)) into two clarified grape juices (Chardonnay and Sauvignon blanc juices) with heat treatment (at $750^{\circ} \mathrm{C}$, $1 \mathrm{~min}$ ) and without heat treatments prior to fermentation exhibited about $20 \%$ total protein reduction as compared to the control wine. However, it showed the best activity when the enzymes were combined with juice heating $(\approx 90 \%$ total protein reduction). But the more heat-stable grape proteins (i.e., those do not contribute to wine hazing) were not affected by the treatments and hence account for the remaining $10 \%$ of proteins still found in the solution after the treatments. The major physicochemical parameters and sensorial characteristics of wines produced with AGP were comparable with the control [42].

The application of Aspergilloglutamic peptidase (AGP) (commercially known as Proctase and formerly known as Aspergillopepsin II) to clarified grape juice prior to flash pasteurization and fermentation resulted in heat-stable wines that were completely free from haze-forming proteins. The results of chemical and sensory analysis also indicated that there were no significant changes in physicochemical parameters of wine preference. This combined use of protease with flash pasteurization has been shown to be effective at industrial scale, and consequently, the use of AGP in wine has been recently accepted in Australian winemaking. The overall cost of AGP application is comparable to bentonite treatment, and this makes AGP a potentially cost-effective and commercially viable alternative for bentonite [41].

The clarification of blackcurrant juice with acid protease (Enzeco and Novozyme 89L) after precentrifugation and cold storage showed a significant reduction in haze development. The addition of Enzeco protease (conc. $0.025 \mathrm{~g} / \mathrm{L}$ ) and gallic acid (conc. $0.050 \mathrm{~g} / \mathrm{L}$ ) into blackcurrant juice and allowing it to react in the juice for $90 \mathrm{~min}$ at $50^{\circ} \mathrm{C}$ showed the lowest levels of haze formation after 28 days of storage at $20^{\circ} \mathrm{C}$ [43]. In other studies, the treatment of cherry juice with protease (Enzeco, enzyme preparations derived from Aspergillus spp.) resulted in a considerable reduction in immediate turbidity but had low clarification impact during the subsequent cold storage [44]. The combined treatment of wines with heat $\left(90^{\circ} \mathrm{C}\right.$ for 1 minute) and enzymes (Trenolin blank, a mixed pectolytic and proteolytic enzyme solution and porcine pepsin) also reduced $40 \%-80 \%$ of the protein level in wines [45].

The treatment of banana juice extracted from the banana pulp by two selected commercial protease enzymes (zumizyme and papaine) during banana wine making indicated that the wine turbidity was significantly reduced as compared to the control. These proteases had also shown a substantial effect on the protein haze removal after periods of one week and four weeks. Moreover, a longer incubation period leads to a higher decrease in turbidity. Based on the sensorial analysis, the overall organoleptic quality of the wine did not show significant variation than the control $(p>0.05)$ [46].

The application of BcAP8 (Botrytis aspartic protease) from the grape fungal pathogen Botrytis cinerea, into Australian Semillon and Sauvignon blanc juices, noticeably degraded chitinase, a major class of haze-forming proteins without heat denaturation. Therefore, BcAP8 could potentially benefit winemakers by removing haze-forming proteins under normal winemaking conditions [12]. The extracellular acid protease secreted by Saccharomyces cerevisiae PIR1 during alcoholic fermentation was also found to be active against grape proteins (molecular mass $\approx 25 \mathrm{kDa}$ ) at $38^{\circ} \mathrm{C}$ and $\mathrm{pH} 3.5$ [47].

In another study, the wines treated with protease enzyme have been shown to have a higher amino acid contents than the nonenzyme-treated wines except for arginine and histidine. These results indicated that protease treatment could enhance the concentration of assimilable nitrogen, which was one of the important nutrients for yeast in wine fermentation [48].

\section{Conclusions}

Aspartic protease enzyme has a wide range of application in food and beverage industries, such as cheese industry, bakery industry, and beer and wine industry. The microbial aspartic protease enzyme produced from bacteria and fungi were used for the production of curd in cheese manufacturing, for haze removal in brewery and winery, and for modification of bread in the bakery.

\section{Conflicts of Interest}

The authors declare that they have no conflicts of interest.

\section{References}

[1] C. Sandhya, K. Madhavan Nampoothiri, and A. Pandey, "Microbial protease," in Microbial Enzyme and Biotransformation, J. L. Barredo, Ed., pp. 165-180, Humana Press Inc., Totowa, NJ, USA, 1st edition, 2005.

[2] B. M. Dunn, "Introduction to the aspartic proteinase family," in Overview of Aspartic Acid Proteases, A. K. Ghosh, Ed., pp. 3-21, Wiley-VCH Verlag GmbH \& Co. KGaA, Weinheim, Germany, 2010.

[3] S. Yegin and P. Dekker, "Progress in the field of aspartic proteinases in cheese manufacturing: structures, functions, catalytic mechanism, inhibition, and engineering," Dairy Science \& Technology, vol. 93, no. 6, pp. 565-594, 2013.

[4] M. B. Rao, A. M. Tanksale, M. S. Ghatge, and V. V. Deshpande, "Molecular and biotechnological aspects of microbial proteases," Microbiology and Molecular Biology Reviews, vol. 62, no. 3, pp. 597-635, 1998.

[5] L. W. Theron and B. Divol, "Microbial aspartic proteases: current and potential applications in industry," Applied Microbiology and Biotechnology, vol. 98, no. 21, pp. 8853-8868, 2014.

[6] A. Sumantha, C. Larroche, and A. Pandey, "Microbiology and industrial biotechnology of food-grade proteases: a perspective," Food Technology and Biotechnology, vol. 44, no. 2, pp. 211-220, 2006.

[7] S. Yegin, M. Fernandez-Lahore, A. Jose Gama Salgado, U. Guvenc, Y. Goksungur, and C. Tari, "Aspartic proteinases from Mucor spp. in cheese manufacturing," Applied Microbiology and Biotechnology, vol. 89, no. 4, pp. 949-960, 2011.

[8] T. A. S. Silva, A. Knob, C. R. Tremacoldi, M. R. BrochettoBraga, and E. C. Carmona, "Purification and some properties of an extracellular acid protease from Aspergillus clavatus," World Journal of Microbiology and Biotechnology, vol. 27, no. 11, pp. 2491-2497, 2011. 
[9] D. S. Schomburg, Enzyme Handbook 16, First Supplement Part 2, Class 3: Hydrolases, pp. 259-299, Springer-Verlag, Berlin, Heidelberg, Germany, 1998.

[10] Committee N, “The enzyme list class 5-isomerases," Enzyme, pp. 1-58, 2010.

[11] F. C. M. Vega-Herná and M. C. Aspartic, "Proteases used in cheese making," in Industrial Enzyme, Structure, Function and Applications, J. Polaina and A. P. MacCabe, Eds., pp. 207-220, Springer, Dordrecht, Netherlands, 2007.

[12] S. S. C Van, N. I. Warnock, S. Schmidt et al., "Aspartic acid protease from Botrytis cinerea removes haze-forming proteins during white winemaking," Journal of Agricultural and Food Chemistry, 2013.

[13] M. Jacob, D. Jaros, and H. Rohm, "Recent advances in milk clotting enzymes," International Journal of Dairy Technology, vol. 64, no. 1, pp. 14-33, 2011.

[14] S. M. Cutfield, E. J. Dodson, B. F. Anderson et al., "The crystal structure of a major secreted aspartic proteinase from Candida albicans in complexes with two inhibitors," Structure, vol. 3, no. 11, pp. 1261-1271, 1995.

[15] J. Hill and L. H. Phylip, "Bacterial aspartic proteinases," FEBS Letters, vol. 409, no. 3, pp. 357-360, 1997.

[16] R. Cruz, P. Huesgen, S. P. Riley et al., "RC1339/APRc from Rickettsia conorii is a novel aspartic protease with properties of retropepsin-like enzymes," PLoS Pathogens, vol. 10, no. 8, 2014.

[17] M. T. Chen, Y. Y. Lu, and T. M. Weng, "Comparison of milkclotting activity of proteinase produced by Bacillus subtilis var, natto and Rhizopus oligosporus with commercial rennet," Asian-Australasian Journal of Animal Sciences, vol. 23, no. 10, pp. 1369-1379, 2010.

[18] Z. An, X. He, W. Gao, W. Zhao, and W. Zhang, "Characteristics of miniature cheddar-type cheese made by microbial rennet from Bacillus amyloliquefaciens: a comparison with commercial calf rennet," Journal of Food Science, vol. 79, no. 2, pp. 214-221, 2014.

[19] V. Mandujano-gonzález, L. Villa-tanaca, M. A. Anduchoreyes, and Y. Mercado-flores, "Secreted fungal aspartic proteases: a review," Revista Iberoamericana de Micología, vol. 33, no. 2, pp. 76-82, 2016.

[20] M. J. C. Crabbe, "Rennets: general and molecular aspects," in Cheese Chemistry, Physics and Microbiology, R. F. Fox, P. L. H. McSweeney, and T. M. G. Cogan, Ed., pp. 19-45, Elsevier Ltd., Madison, WI, USA, 3rd edition, 2004.

[21] H. M. Abbas, M. S. Foda, J. M. Kassem, H. M. Bayomi, and M. E. Moharam, "Production of white soft cheese using fungal coagulant produced by solid state fermentation technique," Biocontrol Science and Technology, vol. 25, no. 6, pp. 939-944, 2013.

[22] A. E. A. Amer, M. I. Hashem, M. E. Amer, and A. M. Gomaa, "Using sweet whey for production of milk clotting enzyme by Mucor miehei NRRL 3420 in production of white soft cheese," Middle East Journal of Applied, vol. 5, no. 4, pp. 1068-1081, 2015.

[23] F. Fazouane-Naimi, A. Mechakra, R. Abdellaoui et al., "Characterization and cheese-making properties of rennetlike enzyme produced by a local algerian isolate of Aspergillus niger," Food Biotechnology, vol. 24, no. 3, pp. 258-269, 2010.

[24] A. Lee and H. Nikraz, "BOD: COD ratio as an indicator for river pollution," International Journal of Environmental Science and Technology, vol. 51, no. 26, pp. 139-142, 2015.

[25] T. Ozcan and U. E. Vapur, "Effect of different rennet type on physico-chemical properties and bitterness in white cheese," International Journal of Environmental Science and Development, vol. 4, no. 1, pp. 71-75, 2013.
[26] I. A. A. A. Ayana, A. E. Ibrahim, and W. I. A. Saber, "Statistical optimization of milk clotting enzyme biosynthesis by Mucor mucedo KP736529 and its further application in cheese production," International Journal of Dairy Science, vol. 10, no. 2, pp. 61-76, 2015.

[27] J. Sai manassa, N. Shalini, N. Y. V. Lakshmi, and M. R. Shailaja, "Production of cheese from Rennet enzyme using Rhizomucor miehei isolated from cow dung," Helix, vol. 3, pp. 169-172, 2012.

[28] S. M’hir, C. G. Rizzello, R. Di Cagno, A. Cassone, and M. Hamdi, "Use of selected enterococci and Rhizopus oryzae proteases to hydrolyse wheat proteins responsible for celiac disease," Journal of Applied Microbiology, vol. 106, no. 2, pp. 421-431, 2009.

[29] E. E. Babiker, N. Fujisawa, N. Matsudomi, and A. Kato, "Improvement in the functional properties of gluten by protease digestion or acid hydrolysis followed by microbial transglutaminase treatment," Journal of Agricultural and Food Chemistry, vol. 44, no. 12, pp. 3746-3750, 1996.

[30] J. A. Curiel, R. Coda, A. Limitone et al., "Manufacture and characterization of pasta made with wheat flour rendered gluten-free using fungal proteases and selected sourdough lactic acid bacteria," Journal of Cereal Science, vol. 59, no. 1, pp. 79-87, 2014.

[31] L. Deng, Z. Wang, S. Yang et al., "Improvement of functional properties of wheat gluten using acid protease from Aspergillus usamii," PLoS One, vol. 11, no. 7, pp. 1-13, 2016.

[32] G. Janssen, C. Christis, Y. Kooy-Winkelaar et al., "Ineffective degradation of immunogenic gluten epitopes by currently available digestive enzyme supplements," PLoS One, vol. 10, no. 6, Article ID e0128065, pp. 1-15, 2015.

[33] M. J. Lewis and A. S. Lewis, "Correlation of beer foam with other beer properties," vol. 40, no. 2, pp. 114-124, 2003.

[34] E. Steiner, T. Becker, and M. Gastl, "Turbidity and haze formation in beer-insights and overview," Journal of the Institute of Brewing, vol. 116, no. 4, pp. 360-368, 2010.

[35] M. Lopez and L. Edens, "Effective prevention of chill-haze in beer using an acid proline-specific endoprotease from Aspergillus niger," Journal of Agricultural and Food Chemistry, vol. 53, no. 20, pp. 7944-7949, 2005.

[36] C. A. Bilinski, I. Russell, and G. G. Stewart, “Applicability of yeast extracellular proteinases in brewing: physiological and biochemical aspects," Applied and Environmental Microbiology, vol. 53, no. 3, pp. 495-499, 1987.

[37] J. Finn, A. Surrel, L. Robinson et al., "Investigation of the impact of proline specific endoproteinase on malt haze-active and foam-active proteins," pp. 1-3, 2008.

[38] D. L. Goode, H. H. Wijngaard, and E. K. Arendt, "Mashing with unmalted barley-impact of malted barley and commercial enzyme (Bacillus spp.) additions," MBAA Technical Quarterly, vol. 42, no. 3, pp. 184-198, 2005.

[39] Z. P. Guo, L. Zhang, Z. Y. Ding, Z.-X. Wang, and G.-Y. Shi, "Improving the performance of industrial ethanol-producing yeast by expressing the aspartyl protease on the cell surface," Yeast, vol. 27, no. 12, pp. 1017-1027, 2010.

[40] M. P. Piddocke, A. Fazio, W. Vongsangnak et al., "Revealing the beneficial effect of protease supplementation to high gravity beer fermentations using "-omics" techniques," Microbial Cell Factories, vol. 10, no. 1, p. 27, 2011.

[41] S. C. Van Sluyter, J. M. McRae, R. J. Falconer et al., "Wine protein haze: mechanisms of formation and advances in prevention," Journal of Agricultural and Food Chemistry, vol. 63, no. 16, pp. 4020-4030, 2015.

[42] M. Marangon, S. C. Van Sluyter, E. M. C. Robinson et al., "Degradation of white wine haze proteins by Aspergillopepsin 
I and II during juice flash pasteurization," Food Chemistry, vol. 135, no. 3, pp. 1157-1165, 2012.

[43] A. K. R. Landbo, M. Pinelo, A. F. Vikbjerg, M. B. Let, and A. S. Meyer, "Protease-assisted clarification of black currant juice: synergy with other clarifying agents and effects on the phenol content," Journal of Agricultural and Food Chemistry, vol. 54, no. 18, pp. 6554-6563, 2006.

[44] M. Pinelo, B. Zeuner, and A. S. Meyer, "Juice clarification by protease and pectinase treatments indicates new roles of pectin and protein in cherry juice turbidity," Food and Bioproducts Processing, vol. 88, no. 2-3, pp. 259-265, 2010.

[45] K. F. Pocock, P. B. Høj, K. S. Adams, M. J. Kwiatkowski, and E. J. Waters, "Combined heat and proteolytic enzyme treatment of white wines reduces haze forming protein content without detrimental effect," Australian Journal of Grape and Wine Research, vol. 9, no. 1, pp. 56-63, 2003.

[46] R. P. Van, W. Kyamuhangire, and P. O. Box, "The influence of commercial enzymes on wine clarification and on the sensory characteristics of wines made from three bana," American Journal of Biotechnology and Molecular Sciences, pp. 41-62, 2013.

[47] B. Younes, C. Cilindre, S. Villaume, M. Parmentier, P. Jeandet, and Y. Vasserot, "Evidence for an extracellular acid proteolytic activity secreted by living cells of Saccharomyces cerevisiae PIR1: impact on grape proteins," Journal of Agricultural and Food Chemistry, vol. 59, no. 11, pp. 6239-6246, 2011.

[48] W. Zhang, L. Zhang, and C. Xu, "Chemical and volatile composition of jujube wines fermented by Saccharomyces cerevisiae with and without pulp contact and protease treatment," Food Science and Technology, vol. 36, no. 2, pp. 204-209, 2016. 


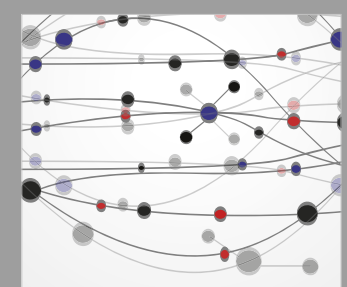

The Scientific World Journal
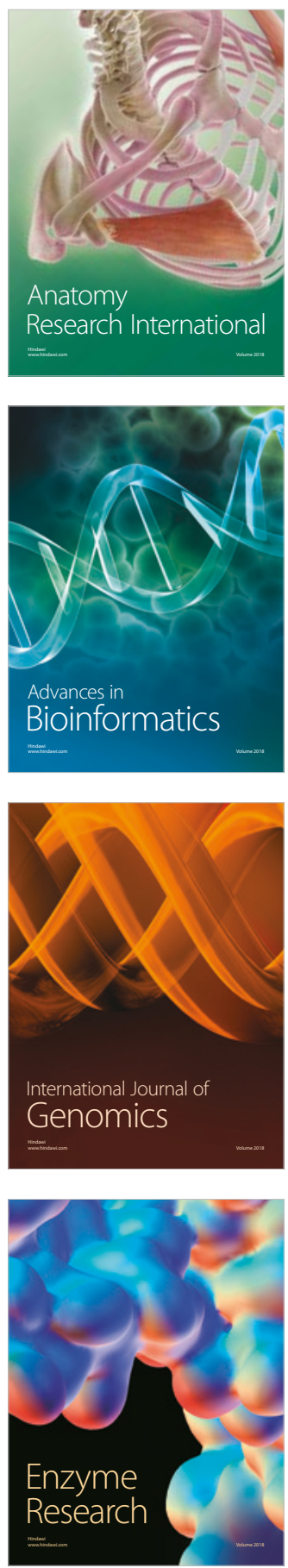
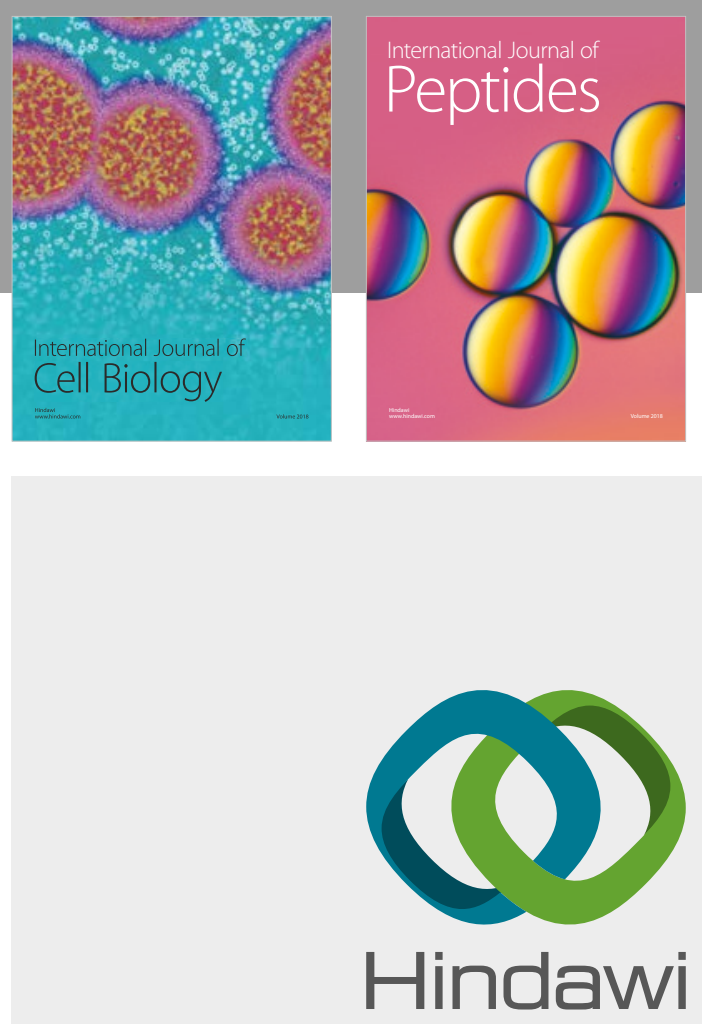

Submit your manuscripts at

www.hindawi.com
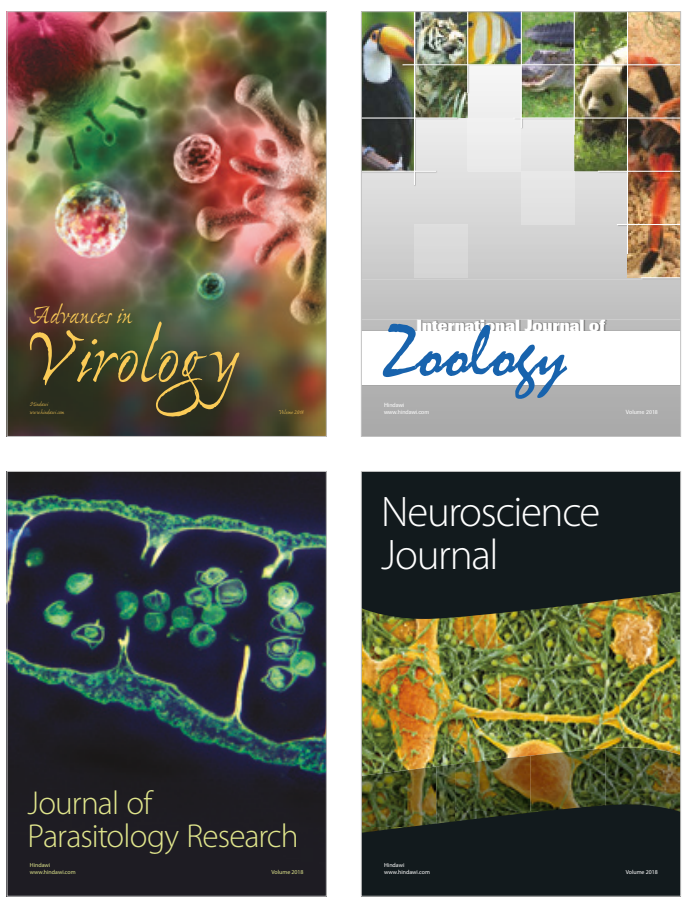
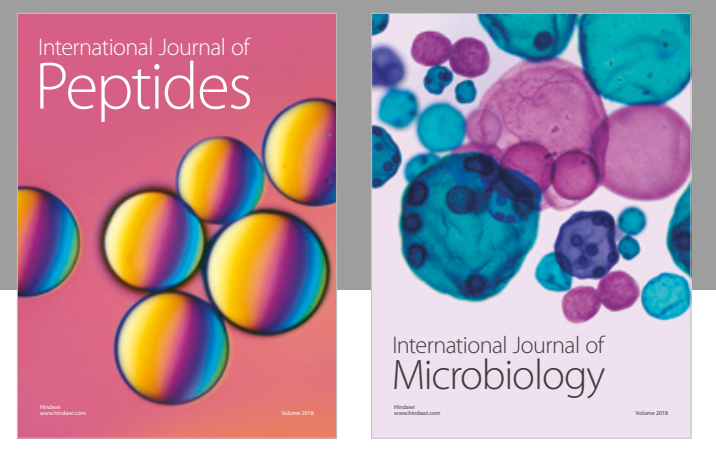

nternational Journal of Microbiology
Journal of
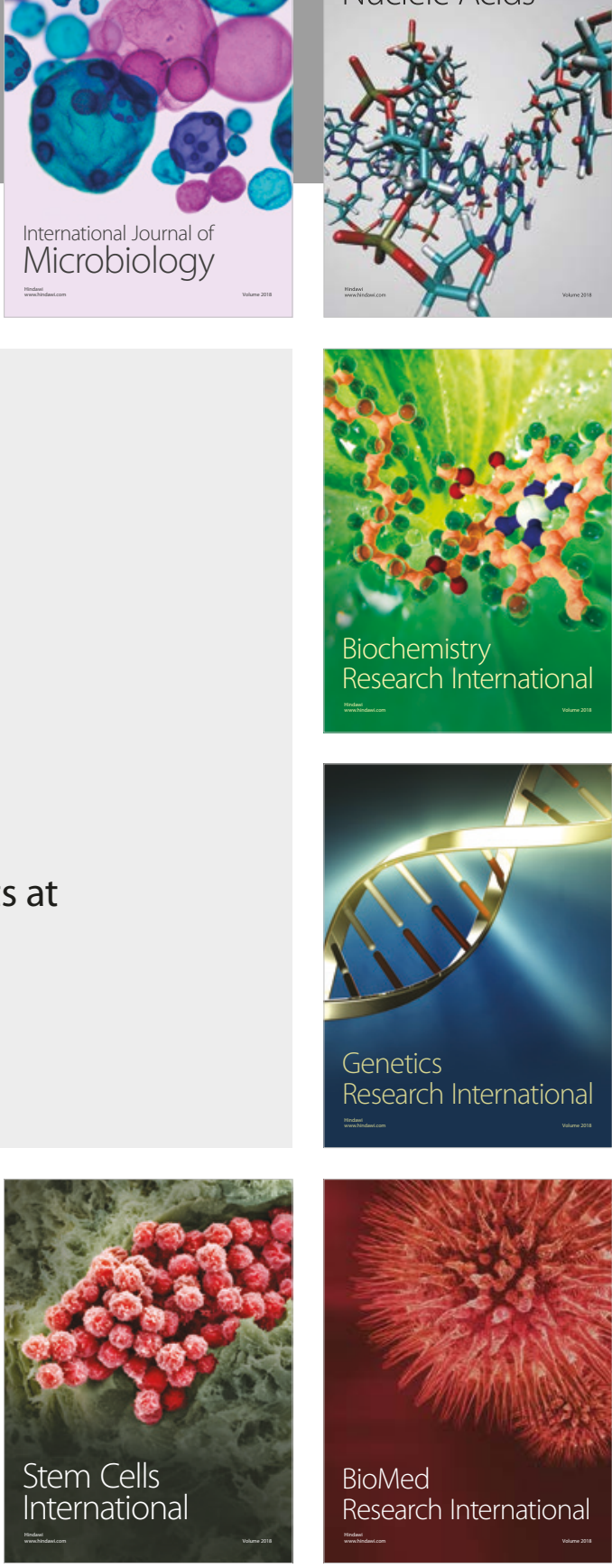
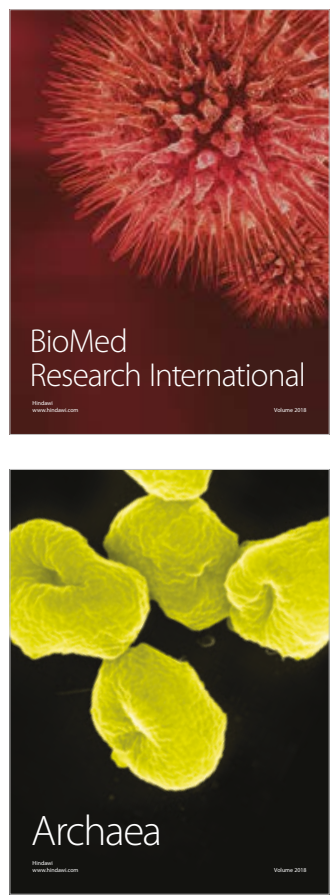